\title{
Evaluation of Advanced Bread Wheat Lines for Field and Seedling Resistance to Stem Rust (Puccinia graminis f. sp. tritici)
}

\author{
Bekele Hundie $^{1}$, Fikirte Yirga ${ }^{1}$, Daniel Kassa ${ }^{1}$, Endale Hailu ${ }^{2}$, Tamirat Negash ${ }^{1}$, Tsegaab Tesfaye ${ }^{2}$, \\ Netsanet Bacha ${ }^{2}$, Yewubdar Shewaye ${ }^{1}$, Getaneh Woldeab ${ }^{2}$, Habte Zegaye ${ }^{1}$, Zerihun Tadesse ${ }^{1}$, \\ Bedada Girma ${ }^{1}$
}

${ }^{1}$ Ethiopian Institute of Agricultural Research (EIAR), Kulumsa Agricultural Research Center, Asella, Ethiopia

${ }^{2}$ Ambo Plant Protection Research Center, Ambo, Ethiopia

\section{Email address:}

bekelehundie@yahoo.com (B. Hundie), bedadagbuta@gmail.com (B. Girma), endalehailu@gmail.com (E. Hailu), fikryirga@gmail.com (F. Yirga), danieyobe@yahoo.com (D. Kassa), tamnegu@gmail.com (T. Negash), tsegabye2003@gmail.com (T. Tesfaye), netsanetbacha@yahoo.com (N. Bacha), getanehwoldeab@gmail.com (G. Woldeab), habteenn@gmail.com (H. Zegaye), zerbest.2008@gmail.com (Z. Tadasse), yewb21@gmail.com (Y. Shewaye)

\section{To cite this article:}

Bekele Hundie, Fikirte Yirga, Daniel Kassa, Endale Hailu, Tamirat Negash, Tsegaab Tesfaye, Netsanet Bacha, Yewubdar Shewaye, Getaneh Woldeab, Habte Zegaye, Zerihun Tadesse, Bedada Girma. Evaluation of Advanced Bread Wheat Lines for Field and Seedling Resistance to Stem Rust (Puccinia graminis f. sp. tritici). American Journal of Biological and Environmental Statistics.

Vol. 4, No. 2, 2018, pp. 74-82. doi: 10.11648/j.ajbes.20180402.14

Received: May 2, 2018; Accepted: July 23, 2018; Published: August 28, 2018

\begin{abstract}
Field-based adult plant resistance assessment at multi-location rust hot spot sites is a crucial job for those plant pathologists screening several wheat lines at a time against the rusts. Rust resistant bread wheat genotypes that have been extracted from previous studies have sustained wheat production in Ethiopia. The objective of this study was to evaluate advanced bread wheat lines extracted from wheat breeding trials against stem rust at adult plat stage under stem rust hot spot sites and at seedling stages in the greenhouse. Eighty three lines were further re-evaluated in consecutive two years. Check varieties were included for comparison. High disease pressure was developed on adult plant in the trial as it has been revealed by high severity on susceptible check varieties. Over years average final rust severity, co-efficient of infection and field reaction have used for differentiating Adult plant resistances. Based on ACI, the 843 genotypes evaluated in initial trial in 2013 were categorized into 10 resistance levels, of which 188 genotypes were in high level resistance category, revealing that various level of adult plant resistance is operating in these test materials. Most of 83 genotypes r-evaluated in consecutive two years after initial stage have sustained low final stem rust severity and coefficient of infection as compared with check varieties. Genotypes were varied by adult plant reaction to stem rust, however, lines ETBW7818, ETBW7819, ETBW7258, ETBW 8008, ETBW 8009, ETBW 8017, ETBW 8027, ETBW 8052, ETBW 8054 and ETBW 8055 concisely showed a reaction of $\mathrm{R}$ to $\mathrm{R}-\mathrm{MR}$ invariably with environments. Of the 83 lines tested at seedling stages against four races, 21 lines exhibited resistance to three races JRCQC, TKTTF, TTKSK and TRTTF whereas 24 lines showed susceptibility to the latter three races. Based on adult reaction, final disease severity and coefficient of infection data, Sixty six bread wheat lines and two cultivars Shorima and Huluka sustained final rust severity $\leq 30 \%$ and low ACI are acceptable for rust resistance breeding in wheat, However, 52 lines showed comparable resistance to Shorima or Hulluka are the priority materials to be used for developing resistant cultivars potentially combining non-race specific and race specific genes which is more durable than cultivars with major resistance gene effect and more efficient than sole adult plant resistance. Inherent resistance genes of these lines are unknown and warrant further description.
\end{abstract}

Keywords: Bread Wheat, Puccinia graminis, Adult Plant Resistance, Partial Resistance, Seedling Resistance, All Stage Resistance 


\section{Introduction}

Ethiopia is the second largest wheat producing country in sub-Saharan Africa with two seasons of wheat crops per annum. Crops of meher season is planted between June and Aug, and harvested in November/December while the belg season crop planting is done in April and harvesting is carried out during July/August [1]. Wheat grains of 4.5 million tons are produced on 1.6 million hectares annually. Yet, productivity of wheat remains low at $2.67 \mathrm{t} /$ ha [2]. Low wheat productivity is implicated to biotic and abiotic constraints. Rusts, especially stem rust and yellow rust are most widely distributed in four major wheat producing regions and greatly contribute to the low wheat productivity [3-6]. Stem rust is a major disease in East Africa, and yellow rust is a major disease in 12 countries globally [7]. In Ethiopia, stem rust and yellow rust incur actual yield losses as high as $42-52 \%$ and $20-71 \%$, respectively, in the meher season $[4-5,8]$. These yield loss figures are quite large for a country such as Ethiopia where a great majority of people are food insecure. Two disease management options, genetic resistance and chemical, are the most important rust management strategies in Ethiopia and worldwide [7,9]. Several wheat genotypes with various levels of resistance backgrounds were derived from previous rust resistance screening efforts were recommended for stem resistance breeding $[4,10]$.

Variability is high in graminis f. sp. tritici population in Ethiopia [11-13]. Of several stem rust races in present graminis f. sp. tritici population in Ethiopia, races TTKSK, TKTTF, TRTTF, JRCQC and TTTTF threats to wheat production currently. Digalu race, TKTTF, destructed the popular bread wheat variety Digalu in Ethiopia and led to up to $100 \%$ yield loss in 2013-2015 [13].

Of the rust resistance types, resistance controlled by major $\mathrm{R}$-genes is not long lasting, not durable [14] due to new races evolving in pathogen populations causing rusts through climatic changes [15], sexual and para-sexual recombination [16-17] and migration of the virulent forms into new regions $[7,18]$ and defeating resistance genes deployed to commercial varieties. Partial resistance which is determined by minor genes and expressed under field condition is considered durable in combating wheat rust as compared to resistance determined by aforementioned R-genes although both resistance types have a complementary effect on extending rust management durability. Resistance sources to rusts are searched at regular bases by pathologists and breeders. From 2013 to 2015, several bread wheat advanced lines extracted from wheat breeding trials were evaluated for stem rust resistance at stem rust hot spot sites and at seedling stages. This paper presents the findings of this study.

\section{Materials and Methods}

\subsection{Field Screening for Adult Plant Resistance}

In main wheat growing season, locally called meher season in 2013, 843 bread wheat genotypes, composed of 836 advanced lines from wheat breeding program: observation nurseries and yield trials, 5 known commercial cultivars (K6295-4A, Kakaba, Alidoro, Danda'a and Digalu, two susceptible check varieties Kubsa and PBW343 and resistant cultivars of recent release Shorima and Huluka) were included planted in two - four rows $(1 \mathrm{~m} \times 0.4-0.8 \mathrm{~m})$ at stem rust hot spot sites. Eighty three genotypes were retained from 2013 field screening nursery and were further evaluated in 2014 and2015. The ETBW code number and pedigree of the 83 materials evaluated over years are given in Table 1. Natural stem rust epidemic was enhanced by two spreader rows composed of mixed susceptible cultivars PBW343, Kubsa and Morocco in 2013 and 2014, and mixture of Digalu and the aforementioned susceptible cultivars in 2015. Spreader rows were planted in perpendicular to the test entries [19].

Weeds were managed by two times hand weeding. Modified-Cobb scale was used for measuring severity in combination with field reaction [20]. Coefficient infection was calculated by multiplying disease severity with field infection response values $0.0,0.2,0.4,0.8$ and 1.0, representing immune, resistant $(\mathrm{R})$, moderately resistant (MR), moderately susceptible (MS) and susceptible (S) reactions, respectively [21]. Multiple infection responses were calculated by double-weighing of the first infection response. In 2013, resistance of genotypes were compared using average coefficients of infection. Field reaction, average final rust severity and coefficient of infection, previously used by various authors such as [22] for comparing test genotypes and the checks further evaluated in 2014 and 2015.

Table 1. ETBW Code and pedigree of 83 bread wheat lines evaluated against stem rust at adult plant stage and seedling plant stage.

\begin{tabular}{ll}
\hline ETBW Code* & Pedigree \\
\hline 6114 & SOKOLL//SUNCO/2*PASTOR \\
$6109 ; 6130$ & SOKOLL/EXCALIBUR \\
6939 & UTIQUE 96/FLAG-1 \\
7058 & ROLF07//TAM200/TUI/6/WBLL1/4/HD2281/TRAP\#1/3/KAUZ*2/TRAP//KAUZ/5/TACUPETO F2001 \\
7258 & SABA/FLAG-1 \\
6212 & QAFZAH-23/SOMAMA-3 \\
6688 & PBW343*2KUKUNA/PARUS/3/PBW343*2/KUKUNA \\
7580 & CNO79//PF70354/MUS/3/PASTOR/4/BAV92*2/5/HAR311 \\
7590 & MILAN/S87230//BAV92/3/AKURI \#1 \\
$7591 ; 7592$ & WBLL1 $2 /$ TUKURU//CROSBILL \#1 \\
\hline
\end{tabular}




\begin{tabular}{|c|c|}
\hline ETBW Code* & Pedigree \\
\hline $\begin{array}{l}8006 ; 8009 ; 7807 ; 7809 ; 7998 ; 8003 ; 8008 ; \\
7808\end{array}$ & SERI.1B//KAUZ/HEVO/3/AMAD/4/FLAG-2 \\
\hline $\begin{array}{l}8012 ; 8017 ; 8018 ; 8027,8015 ; 8022 ; 8021 \\
8023 ; 8024 ; 8014 ; 8016 ; 8019 ; 8020\end{array}$ & PAVON 76/FLAG-3 \\
\hline 8028 & QAFZAH-16/ICARDA-SRRL-5 \\
\hline $8042 ; 8043 ; 8044$ & QAFZAH-22/3/MON'S'/ALD'S'//TOWPE'S' \\
\hline 8055 & SOMAMA-9/ICARDA-SRRL-2 \\
\hline 6161 & $\begin{array}{l}\text { CROC_1/AE.SQUARROSA } \\
(213) / / \text { PGO/10/ATTILA*2/9/KT/BAGE//FN/U/3/BZA/4/TRM/5/ALDAN/6/SERI/7/VEE\#10/8/OPATA }\end{array}$ \\
\hline 6861 & WAXWING*2/HEILO \\
\hline 6921 & $\begin{array}{l}\text { ALTAR 84/AE.SQUARROSA (221) } \\
\text { //3*BORL95/3/URES/JUN//KAUZ/4/WBLL1*2/5/REH/HARE//2*BCN/3/CROC_1/AE.SQUARROSA } \\
(213) / / \text { PGO/4/HUITES }\end{array}$ \\
\hline 7523 & PBW343*2/KHVAKI//JUCHI \\
\hline 7207 & CHAM-4/SHUHA'S'/6/2*SAKER/5/RBS/ANZA/3/KVZ/HYS//YMH/TOB \\
\hline $7567 ; 7568$ & $\mathrm{KFA} / 2 * \mathrm{KACHU}$ \\
\hline 7681 & OASIS/SKAUZ//4*BCN*2/3/PASTOR/4/HEILO/5/PAURAQ \\
\hline 7810 & ENKOY/FLAG-5 \\
\hline $7814 ; 7813$ & KBG-01/FLAG-7 \\
\hline $7815 ; 7819 ; 7817 ; 7816 ; 7818$ & K6295-4A/FLAG-8 \\
\hline 7853 & $\begin{array}{l}\text { BABAX/LR39//BABAX/4/BJY/COC//PRL/BOW/3/FRTL/5/CROC_1/AE.SQUARROSA } \\
\text { (205)//BORL95/3/KENNEDY }\end{array}$ \\
\hline 7912 & CHIH95.7.4//INQALAB 91*2/KUKUNA \\
\hline 7915 & W15.92/4/PASTOR//HXL7573/2*BAU/3/WBLL1 \\
\hline $7966 ; 7962 ; 7965$ & DIGELU/(BOW/FENGKANG15) \\
\hline $7976 ; 7977$ & K6295-4A/ETBW4919 \\
\hline $8045 ; 8052 ; 8054 ; 8048 ; 8049 ; 8051$ & QAFZAH-35/AMIR-2 \\
\hline 6696 & PBW343*2/KUKUNA//SRTU/3/PBW343*2/KPASTOR \\
\hline 6847 & ROLF07*2/5/REH/HARE//2*BCN/3/CROC_1/AE.SQUARROSA (213)//PGO/4/HUITES \\
\hline 6911 & REH/HARE//2*BCN/3/CROC_1/AE.SQUARROSA (213)//PGO/4/HUITES/5/PVN \\
\hline 7008 & QAFZAH-5/ANGI-2//BOW \#1/FENGKANG 15 \\
\hline 7092 & ALD/CEP75630//CEP75234/PT7219/3/BUC/BJY/4/CBRD/5/TNMU/PF85487 \\
\hline 7100 & OASIS/SKAUZ//4*BCN/3/PASTOR/4/KAUZ*2/YACO//KAUZ \\
\hline 7189 & NS732/HER//MILAN/SHA7 \\
\hline 7255 & AGUILAL/FLAG-3 \\
\hline 7496 & WBLL1*2/BRAMBLING//KACHU \\
\hline 7539 & $\begin{array}{l}\text { SERI.1B*2/3/KAUZ*2/BOW//KAUZ*2/5/REH/HARE//2*BCN/3/CROC_1/AE.SQUARROSA } \\
(213) / / \text { PGO/4/HUITES }\end{array}$ \\
\hline $7554 ; 7582$ & SAUAL/YANAC//SAUAL \\
\hline 7587 & FRNCLN/BECARD \\
\hline 7820 & FLAG-6/ICARDA-SRRL-6 \\
\hline 7825 & AMIR-2/TAJAN \\
\hline
\end{tabular}

* ETBW Code $=$ Ethiopian Bread Wheat Code Number

\subsection{Greenhouse Seedling Evaluation}

Five seeds of each 83 bread wheat lines listed in Table 1 were raised to five seedlings in pots in the greenhouse. Urediospores of rust races TKTTF, TTKSK, TRTTF and JRCQC with different virulence spectrum (Table2) were suspended in capsules and sprayed on seven day old seedlings using the methods and procedures developed by [23] and then placed in dew chamber for $18 \mathrm{hrs}$ dark at 18 to $22^{\circ} \mathrm{C}$ followed by the exposure of the materials to light for 3 to $4 \mathrm{hrs}$ in order to provide condition for infection. Then the seedlings were transferred to the growth room in the green house where conditions were regulated at $12 \mathrm{hr}$ photoperiod, 18 to $25{ }^{\circ} \mathrm{C}$ and 60 to $70 \%$ relative humidity. Stem rust infection types were noted at 14 days after inoculation using 0 to 4 rating scale; scorings of $0-2$ and 3-4 values in $0-4$ scale represented resistance and susceptible infection types, respectively. Race TKTTF is new stem rust race which has caused sudden epidemic in Bale zone in 2013 and further spread to Arsi and West-Shewa zone and resulted in severe epidemics and damaged the Digalu cultivar [13]. The race is a dominant stem rust race in current pathogen population in Ethiopian wheat production agro-ecologies.

Table 2. Virulence spectra of the test four stem rust races used for screening the germplasm at seedling plant stage.

\begin{tabular}{lll}
\hline Races & Virulence & A virulence \\
\hline TKTTF & $5,21,9 e, 7 b, 6,8 a, 9 g, 36,9 b, 30,17,9 a, 9 d, 10, T m p, 38, M c N$ & $11,24,31$ \\
TRTTF & $5,21,9 e, 7 b, 11,6,9 g, 36,9 b, 30,17,9 a, 9 d, 10, T m p, 38, M c N$ & $8 a, 24,31$ \\
TTKSK & $5,21,9 e, 7 b, 11,6,8 a, 9 g, 9 b, 30,17,9 a, 9 d, 10,31,38, M c N$ & $36, T m p, 24$ \\
JRCQC & $21,9 e, 11,6,9 g, 17,9 a, 9 d, M c N$ & $5,7 b, 8 a, 36,9 b, 30,10, T m p, 24,31,38$ \\
\hline
\end{tabular}




\section{Results}

\subsection{Field Screening for Adult Plant Resistance}

Excellent stem rust epidemic pressures were built within the trial at each test location. Stem rust resistance status of 843 genotypes was assessed using average coefficients of infection (ACI) in 2013 and categorized into different resistance groups based on this disease parameter, Figure 1. Out of the total genotypes, 109 and 79 genotypes were grouped into high level of resistance in terms of ACI values, not exceeding $10 \mathrm{ACI}$ and 10.1 to $20 \mathrm{ACI}$, respectively. The remaining test genotypes had ACI values $>20$. According to [24], lines with ACI values of $0-20,21-40$ and 41-60 are regarded as genotypes possessing better, moderate and low levels of partial resistance to yellow rust, respectively. Low ACI values recorded on several genotypes indicating that stem rust partial resistance is present in several bread wheat lines and cultivars have been evaluated. Partial resistance conferred by adult plant resistance is considered durable although it is influenced by changes in environment.

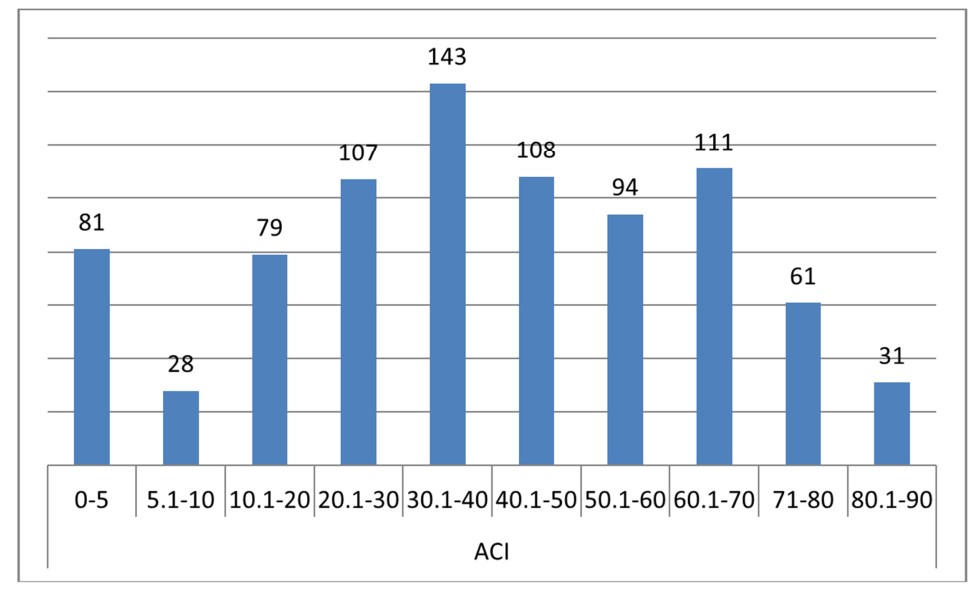

Figure 1. Stem rust resistance diversity of 843 advanced bread wheat lines and varieties as classified based on average coefficient of infection (ACI) of two locations, meher season, 2013.

Eighty three genotypes retained from 2013 field screening activity and further evaluated under field conditions at stem rust hot spot sites were compared using average final rust severity, coefficient of infection and adult plant response derived from the disease data generated during 2013-2015. The results are summarized in Tables 3,4 and 5, based on variability of seedling plant reactions to the four test stem rust races menacing wheat production.

Final rust severity, a cumulative result of all resistance factors involved and inhibiting the progress of disease epidemic [25] and coefficient of infection values recorded on all lines as a whole have been lower than the most susceptible checks indicated in Table 3.

The check cultivars Digalu, Kubsa, Alidoro, Kakaba, and PBW343 had sustained high final rust severity ranging from 39$85.4 \%$ and ACI ranging from 34.8-81.5. The others three checks Danda'a, K6295-4A and Hulluka had the intermediate severity (17.8-28.5\%) and ACI (14.4-34.8) whereas variety shorima had the lowest both final stem rust severity $(6 \%)$ and ACI as low as 3 (Table3). Except lines ETBW 6921 (Table 3), ETBW 7580 (Table4) and ETBW7189, ETBW 7587 (Table5), all the 83 lines had lower final rust severity than check varieties Digalu, Kubsa, Alidoro, Kakaba and PBW343 whereas lines ETBW 6161, ETBW 6696 and ETBW 7539 had a comparable or low level of severity to the rest three check varieties Danda'a, K6295-4A and Hulluka. Of all 83 lines evaluated 52 lines: 13, 17 and 22 lines presented in Tables 3, 4 and 5, respectively, showed lower or comparable disease parameters values recorded on Shorima variety that has an effective resistance gene $\mathrm{Sr} 24$, effective stem rust resistance gene against all major races currently prevailing in Ethiopia. Among these materials with low final rust severity and coefficient of infection, 48 lines were sister lines from various crosses: 13, 8, 6 and 5 lines were from PAVON76/FLAG-3,

SERI.1B//KAUZ/HEVO/3/AMAD/4/FLAG-2, QAFZAH35/AMIR-2 and K6295-4A/FLAG-8 crosses, respectively, whereas each 3 lines were from each QAFZAH22/3/MON'S'/ALD'S'//TOWPE'S',

DIGELU/(BOW/FENGKANG15). Each two lines were from each SOKOLL/EXCALIBUR, WBLL1*2/TUKURU//CROSBILL\#1, KFA/2*KACHU, KBG01/FLAG-7 and SAUAL/YANAC//SAUAL crosses. According to [26], final rust severity, an epidemiological parameter, can effectively measure slow rusting; a kind of partial resistance in wheat.

Genotypes reaction to stem rust at adult plant stages showed variation. Few lines such as ETBW7818 and ETBW7819 had exhibited resistance reaction $(\mathrm{R})$ while other lines such as ETBW7258, ETBW 8008, ETBW 8009, ETBW 8017, ETBW 8027, ETBW 8052, ETBW 8054 and ETBW 8055 showed R-MR response invariably with locations and years. The rest of the lines had various combinations of disease reactions. Lines exhibited MS or S type infection and had lower disease progress than the susceptible checks (Tables 3, 4, 5) are expected to possess resistance genes that confer partial resistance to stem rust which is in line with findings of the other authors such as [27]. 
Table 3. Reaction of 21 bread wheat lines to stem rust (severity, reaction, ACI) at adult plant stage and susceptible group to TKTTF, TTKSK and TRTTF races at seedling stage (3- to $3+)$.

\begin{tabular}{|c|c|c|c|c|c|c|c|}
\hline \multirow{2}{*}{ ETBW Code } & \multirow{2}{*}{ Severity } & \multirow{2}{*}{ ACI } & \multirow{2}{*}{ Reaction range } & \multicolumn{4}{|c|}{ Seedling reaction to four stem rust races } \\
\hline & & & & TKTTF & TTKSK & TRTTF & JRCQC \\
\hline ETBW 6130 & 1.36 & 0.86 & R-MSS & $3^{-}$ & $3^{-}$ & $3-$ & $; 1$ \\
\hline ETBW 6161 & 17.27 & 14.72 & MRMS-S & $3-$ & 3 & $3^{-}$ & ;1 \\
\hline ETBW 6861 & 3.36 & 1.60 & R-MS & $3^{-}$ & $3^{-}$ & $3^{-}$ & $; 1^{+}$ \\
\hline ETBW 6921 & 37.50 & 31.24 & MS-S & 3 & $2^{+}$ & 3 & ; \\
\hline ETBW 7523 & 12.82 & 10.29 & RMR-S & $3^{-}$ & $3^{-}$ & 3 & 2 \\
\hline ETBW 7207 & 13.27 & 8.34 & MR-S & $3^{-}$ & 3 & $3^{-}$ & $; 1^{+}$ \\
\hline ETBW 7567 & 5.18 & 3.63 & MRMS-S & $3^{-}$ & $3^{-}$ & 3 & 3 \\
\hline ETBW 7681 & 11.09 & 8.06 & MR-S & 3 & $3^{-}$ & $3^{-}$ & $; 1$ \\
\hline ETBW 7808 & 1.82 & 0.3 & R-MS & $3^{-}$ & $3^{-}$ & $3^{-}$ & $; 1^{+}$ \\
\hline ETBW 7810 & 1.36 & 0.30 & R-S & $3^{-}$ & $3^{-}$ & 3 & $3^{-}$ \\
\hline ETBW 7814 & 0.82 & 0.15 & R-MS & 3 & $3^{-}$ & $3^{-}$ & $; 1^{+}$ \\
\hline ETBW 7815 & 2.55 & 0.43 & R-S & $3^{-}$ & $3^{-}$ & $3^{-}$ & $; 1$ \\
\hline ETBW 7817 & 0.36 & 0.12 & $\mathrm{R}-\mathrm{S}$ & 3 & $3^{-}$ & 3 & $; 1$ \\
\hline ETBW 7853 & 0.91 & 0.31 & R-MS & $3^{-}$ & $3^{-}$ & $3^{-}$ & $; 1$ \\
\hline ETBW 7912 & 14.73 & 13.39 & R-SMS & $3^{-}$ & $3^{-}$ & $3^{-}$ & $; 1^{+}$ \\
\hline ETBW 7915 & 9.80 & 16.75 & MR-S & 3 & $3^{-}$ & 3 & $; 2$ \\
\hline ETBW 7966 & 2.18 & 1.11 & R-MSS & 3 & 3 & 3 & ; \\
\hline ETBW 7976 & 2.18 & 0.68 & R-MS & 3 & $3^{-}$ & $3^{-}$ & $; 1^{+}$ \\
\hline ETBW 8015 & 4.55 & 2.25 & $\mathrm{R}-\mathrm{S}$ & $3^{-}$ & $3^{-}$ & 3 & $; 2$ \\
\hline ETBW 8022 & 1.27 & 0.23 & R-S & 3 & 3 & 3 & $; 1^{+}$ \\
\hline ETBW 8045 & 2.91 & 0.94 & R-MS & $3^{-}$ & $3^{-}$ & $3^{-}$ & $3^{-}$ \\
\hline Digalu & 44.92 & 33.84 & MR-S & - & - & - & - \\
\hline K6295-4A & 17.98 & 33.23 & MSS-SMS & - & - & - & - \\
\hline Kubsa & 48.89 & 39.79 & $\mathrm{~S}$ & - & - & - & - \\
\hline Alidoro & 72.79 & 70.70 & SMS & - & - & - & - \\
\hline Danda'a & 28.50 & 34.80 & MSS-S & - & - & - & - \\
\hline Kakaba & 39.41 & 43.99 & MS-S & - & - & - & - \\
\hline PBW343 & 85.36 & 81.46 & MRMS & - & - & - & - \\
\hline Shorima & 5.52 & 2.94 & RMR-MSS & - & - & - & - \\
\hline Huluka & 17.85 & 14.42 & RMR-MS & - & - & - & - \\
\hline
\end{tabular}

$\mathrm{ACI}=$ Average coefficient of infection; - $=$ no data

Table 4. Reaction of twenty-four bread wheat lines to stem rust (severity, reaction, ACI) at adult plant stage and resistant group to TKTTF, TTKSK, TRTTF and JRCQC races at seedling plant stages $(0-2+)$.

\begin{tabular}{|c|c|c|c|c|c|c|c|}
\hline \multirow{2}{*}{ Entry Code } & \multirow{2}{*}{ Severity } & \multirow{2}{*}{ ACI } & \multirow{2}{*}{ Reaction } & \multicolumn{4}{|c|}{ Seedling reaction to four stem rust races } \\
\hline & & & & TKTTF & TTKSK & TRTTF & JRCQC \\
\hline ETBW 6114 & 2.73 & 2.37 & MR-MSS & ; & $; 1$ & $; 1$ & ; \\
\hline ETBW 6109 & 2.09 & 1.32 & RMR-MS & $2-$ & $2-$ & $2-$ & $2^{-}$ \\
\hline ETBW6939 & 11.17 & 11.10 & MR-S & $2-$ & $2-$ & $2+$ & $; 1+$ \\
\hline ETBW7058 & 5.64 & 6.29 & MR-MSS & $2-$ & $2-$ & 2 & $; 1$ \\
\hline ETBW7258 & 0.33 & 0.15 & R-MR & $2-$ & $2-$ & $2+$ & $; 1$ \\
\hline ETBW 6212 & 9.18 & 7.99 & MS-MSS & $1^{+}$ & ;1 & $; 1^{+}$ & $; 1$ \\
\hline ETBW 6688 & 6.91 & 4.78 & MR-MSS & $2^{-}$ & $; 1^{+}$ & $; 1^{+}$ & ;1 \\
\hline ETBW 7580 & 51.67 & 32.82 & MR-S & $1^{+}$ & $; 1^{+}$ & $; 1^{+}$ & $1^{+}$ \\
\hline ETBW 7590 & 6.09 & 6.51 & MR-MSS & $1^{+}$ & $; 1^{+}$ & $; 1^{+}$ & $; 1$ \\
\hline ETBW 7591 & 5.55 & 6.61 & MR-S & $1^{+}$ & $; 1$ & $; 1^{+}$ & ; \\
\hline ETBW 7819 & 0.09 & 0.03 & $\mathrm{R}$ & ;1 & ;2 & 2 & $; 1^{+}$ \\
\hline ETBW 8006 & 2.18 & 0.36 & R-MS & ;1 & $2^{+}$ & $; 1$ & $; 1$ \\
\hline ETBW 8009 & 3.00 & 0.56 & R-MR & ;2 & $; 2$ & $2^{-}$ & $; 1$ \\
\hline ETBW 8012 & 4.00 & 1.09 & R-MS & $; 2^{-}$ & $; 1^{+}$ & $2^{-}$ & $; 1$ \\
\hline ETBW 8017 & 4.45 & 0.83 & R-MR & ;1 & $2^{+}$ & $; 1^{+}$ & 0 \\
\hline ETBW 8018 & 3.36 & 0.79 & R-MS & $2^{+}$ & $2^{+}$ & $2^{+}$ & $; 1$ \\
\hline ETBW 8027 & 1.18 & 0.25 & R-MR & $2^{-}$ & 2 & $2^{+}$ & $2^{+}$ \\
\hline ETBW 8028 & 2.18 & 0.56 & R-MS & $2^{-}$ & $2^{+}$ & $2^{+}$ & $2^{+}$ \\
\hline ETBW 8042 & 0.36 & 0.25 & R-MS & $; 1^{+}$ & $; 1^{+}$ & $2^{+}$ & $2^{+}$ \\
\hline ETBW 8043 & 4.64 & 1.83 & R-MSS & 2 & $2^{+}$ & $2^{+}$ & $; 1^{+}$ \\
\hline ETBW 8044 & 3.82 & 0.78 & RMR-SMS & ;1 & $; 2^{-}$ & $2^{+}$ & $2^{-}$ \\
\hline ETBW 8049 & 0.67 & 0.37 & MR-MSS & ;2 & $; 1$ & $2^{+}$ & $2^{+}$ \\
\hline ETBW 8051 & 1.82 & 0.58 & R-MS & $2^{+}$ & $2^{+}$ & 2 & $1^{+}$ \\
\hline ETBW 8055 & 2.55 & 1.28 & R-MR & ;1 & ;1 & $2^{+}$ & $2^{+}$ \\
\hline
\end{tabular}

$\mathrm{ACI}=$ Average coefficient of infection 
Table 5. Reaction of 38 bread wheat lines to stem rust (severity, reaction, ACI) at adult stage groups of lines with variable reaction to four stem rust races at seedling plant stages.

\begin{tabular}{|c|c|c|c|c|c|c|c|}
\hline \multirow{2}{*}{ Entry Code } & \multirow{2}{*}{ Severity in \% } & \multirow{2}{*}{ ACI } & \multirow{2}{*}{ Reaction } & \multicolumn{4}{|c|}{ Seedling reaction to four stem rust races } \\
\hline & & & & TKTTF & TTKSK & TRTTF & JRCQC \\
\hline ETBW 6696 & 15.64 & 16.29 & R-SMS & $2-$ & 3 & $2^{+}$ & 2 \\
\hline ETBW 6847 & 8.18 & 8.94 & MR-S & $; 1$ & $3^{-}$ & $2^{-}$ & $; 1$ \\
\hline ETBW 6911 & 11.00 & 9.75 & MSMR-S & $3^{-}$ & $2^{+}$ & $3^{-}$ & ; \\
\hline ETBW 7008 & 12.83 & 15.89 & MR-SMS & $3^{-}$ & $2^{+}$ & $3^{-}$ & $3^{-}$ \\
\hline ETBW 7092 & 8.09 & 5.69 & RMR-MSS & $3^{-}$ & $; 2^{-}$ & 2 & ; \\
\hline ETBW 7100 & 2.73 & 0.31 & RMR-MS & $2^{+}$ & 3 & $2^{-}$ & ; \\
\hline ETBW 7189 & 29.33 & 14.55 & $\mathrm{R}-\mathrm{S}$ & ;2 & $3^{-}$ & $2^{-}$ & $; 1^{+}$ \\
\hline ETBW 7255 & 1.00 & 0.72 & R-MS & $2^{-}$ & $3^{-}$ & $2^{+}$ & $; 1$ \\
\hline ETBW 7496 & 14.73 & 10.52 & MR-S & $3^{-}$ & $; 1$ & $3^{-}$ & 0 \\
\hline ETBW 7539 & 15.27 & 14.29 & RMR-S & $2^{-}$ & $2^{+} 3^{-}$ & $3^{-}$ & $3^{-}$ \\
\hline ETBW 7554 & 4.73 & 3.62 & MR-MSS & $2^{+}$ & $2^{+}$ & $2^{+}$ & $3^{-}$ \\
\hline ETBW 7568 & 7.91 & 4.93 & MR-S & $2^{+}$ & 3 & $2^{+}$ & $2^{-}$ \\
\hline ETBW 7582 & 14.91 & 9.26 & RMR-S & 2 & $3^{-}$ & $; 1^{+}$ & $1^{+}$ \\
\hline ETBW 7587 & 22.91 & 16.02 & MR-S & $3^{-}$ & $2^{+} \mathrm{C}$ & $3^{-}$ & $3^{-}$ \\
\hline ETBW 7592 & 6.55 & 7.88 & MR-S & $2^{+}$ & $3^{-}$ & $2^{-}$ & $; 1$ \\
\hline ETBW 7807 & 1.36 & 0.29 & R-MS & 3 & $2^{+}$ & 3 & $; 1^{+}$ \\
\hline ETBW 7809 & 0.50 & 0.32 & R-MS & $2^{+}$ & $3^{-}$ & ;2 & $; 1^{+}$ \\
\hline ETBW 7816 & 1.27 & 0.66 & R-MSS & $2^{+}$ & $3^{-}$ & $3^{-}$ & ; \\
\hline ETBW 7818 & 0.09 & 0.03 & $\mathrm{R}$ & $; 2$ & $3^{-}$ & $2^{-}$ & $; 1^{+}$ \\
\hline ETBW 7820 & 1.64 & 1.27 & R-SMS & $3^{-}$ & $2^{+}$ & $2^{+}$ & ; \\
\hline ETBW 7825 & 2.91 & 0.82 & R-MS & $3^{-}$ & $2+3$ & $2^{+}$ & ;2 \\
\hline ETBW 7962 & 7.18 & 7.56 & $\mathrm{R}-\mathrm{S}$ & $1^{+}$ & $3^{-}$ & $2^{-}$ & $; 1^{+}$ \\
\hline ETBW 7965 & 1.82 & 1.06 & R-MS & 2 & $2+3^{-}$ & $2^{+}$ & $; 1$ \\
\hline ETBW 7977 & 1.27 & 0.40 & $\mathrm{R}-\mathrm{S}$ & $2^{-}$ & $3^{-}$ & ;2 & $2^{+}$ \\
\hline ETBW 7998 & 5.18 & 3.05 & MR-S & $2^{+}$ & $3^{-}$ & $2^{-}$ & ; \\
\hline ETBW 8003 & 5.36 & 5.17 & MR-MSS & $; 1^{+}$ & $3^{-}$ & $; 1^{+}$ & $; 1$ \\
\hline ETBW 8008 & 1.36 & 0.17 & R-MR & $; 2^{-}$ & $3^{-}$ & $; 1^{+}$ & $1^{+}$ \\
\hline ETBW 7813 & 0.75 & 1.20 & R-MSMR & 2 & $3^{-}$ & 3 & $; 1$ \\
\hline ETBW 8014 & 6.18 & 3.48 & R-S & $2^{+}$ & $3^{-}$ & $2^{+}$ & $; 1^{+}$ \\
\hline ETBW 8016 & 2.55 & 0.64 & R-MS & $2^{+}$ & $3^{-}$ & $2^{+}$ & $; 1$ \\
\hline ETBW 8019 & 1.73 & 0.34 & R-MS & ;2 & $3^{-}$ & $3^{-}$ & 2 \\
\hline ETBW 8020 & 2.18 & 0.46 & R-MS & 2 & 3 & $3^{-}$ & $; 1^{+}$ \\
\hline ETBW 8021 & 1.00 & 0.54 & R-S & $3^{-}$ & $; 2^{+}$ & $3^{-}$ & $3^{-}$ \\
\hline ETBW 8023 & 1.36 & 0.22 & R-MS & $3^{-}$ & $3^{-}$ & $2^{-}$ & $; 1^{+}$ \\
\hline ETBW 8024 & 1.36 & 0.32 & $\mathrm{R}-\mathrm{S}$ & $3^{-}$ & $3^{-}$ & $2^{+}$ & $3^{-}$ \\
\hline ETBW 8052 & 2.73 & 0.73 & R-MR & $2^{+}$ & $2^{+}$ & 3 & $2^{+}$ \\
\hline ETBW 8054 & 3.00 & 0.68 & R-MR & $; 1^{+}$ & $; 1^{+}$ & $2^{+}$ & $3^{-}$ \\
\hline ETBW 8048 & 1.33 & 0.69 & RMR-MS & $2^{-}$ & ;2 & $3^{-}$ & $3^{-}$ \\
\hline
\end{tabular}

$\mathrm{ACI}=$ Average coefficient of infection

\subsection{Greenhouse Seedling Evaluation}

The 83 test genotypes reaction to stem rust races at seedling plant stages showed variation. The results are summarized in the aforementioned Tables 3, 4, 5, based on their variable reactions to the four stem rust races. Twenty four lines ETBW6114, ETBW6109, ETBW 7058, ETBW 6939, ETBW 7258, ETBW6212, ETBW6688, ETBW7580, ETBW7590, ETBW7591, ETBW7819, ETBW8006, ETBW8009, ETBW8012, ETBW8017, ETBW8018, ETBW8027, ETBW8028, ETBW8042, ETBW8043, ETBW8044, ETBW8049, ETBW8051 and ETBW 8055 shown in Table 4 have displayed seedling resistance (reaction of 0 to $2+$ ) to TKTTF, TTKSK, TRTTF and JRCQC races invariably. Twenty one bread wheat genotypes susceptible to three prevailing stem rust races, TKTTF, TTKSK and TRTTF and resistant to JRCQC at are shown in Table 3 of which ETBW 8045 was an exceptional in response, showed susceptibility to all four races. Of the lines shown in Table 5, thirty two lines were resistant to race JRCQC, but, showed variable reactions to the remaining three stem rust races.

\section{Discussion}

Ethiopia is one of the countries where stem rust epidemic is most frequently occurring $[4,28]$. A number of stem rust epidemics have been experienced over many years $[4,6,13$, 29 ] in association with failure of single Sr-resistance gene of major effect deployed to commercial cultivars that lacked adequate genetic diversity in their backgrounds and selecting for virulent races in Puccinia graminis f. sp. tritici population. Since 2003, virulent new stem rust races such as TTKSK, TKTTF, TRTTF, JRCQC and TTTTF have been prevailed in Ethiopian Puccinia graminis population [11-12] and have threatened wheat production. Moreover, virulent races could continue to evolve not only in $P$. graminis $\mathrm{f}$. sp. tritici population for this matter, but also in stem rust races existing in wheat-puccinia pathosystem as demonstrated by 
TTKSK race which evolved into several races within the Ug99 race [13, 17] that adapt to resistant varieties and resulted in severe epidemics and reduce wheat yields.

Among currently existing stem rust races prevail in Ethiopia, race TKTTF is the most predominant and destructive race that significantly halting several resistance genes (Table 2) and the production of the popular bread wheat varieties in major wheat producing areas of the country. The spread and effect of this menace stem rust races is counteracted mainly by growing resistant varieties and fungicide options. Wheat germplasm screening for stem rust resistance is mainly achieved by measuring seedling infection types (resistance) in greenhouse and adult plant reaction, rust severity, ACI and area under disease progress curve derived from adult plant stages under field conditions. The disease parameters we used are similar to many other researchers. Various authors [22, 30-32] used final rust severity, coefficient of infection and area under the disease progress for identifying genotypes possessing partial resistance and all stage resistance in wheat.

From 2013-2015, we have evaluated bread wheat genotypes under heavy stem rust disease pressure developed in the nursery as indicated by high epidemic pressure recorded on susceptible check varieties and spreader rows. High disease pressure developed under condition enabled us to differentiate the genotypes into different resistance categories at adult plant growth stages, and simultaneously proving that screening procedure of wheat germplasm against stem rust at stem rust hot spot multi-location is dependable, despite some escape risks associated with such procedure.

Severity and ACI data generated by present study have revealed that the levels of stem rust resistance of most of the lines are better than resistance of susceptible check varieties PBW343, a variety selecting to TTKSK; Kubsa and Digalu varieties, selecting to TKTTF. Germplasm exhibiting susceptibility at seedling stage and having lower final rust severity, lower ACI and AUDPC than the susceptible checks are expected to have adult plant resistance, a type of partial or slow rusting resistance. Genotypes showed such combinations of disease scores were observed.

Out of 83 genotypes evaluated over years, 52 lines showed lower or comparable disease parameters values recorded on recently released bread wheat varieties Shorima or Hulluka in which the presence of $\mathrm{Sr} 24$ has been confirmed recently (Bekele et. al., unpublished data). Thus, these materials showed lower disease values than these checks probably could have Sr 24 resistance gene in their backgrounds in addition to others unknown resistance genes. Sr24 is resistant to TKTTF and TTKSK races at seedling plant stage in Ethiopia [30]. According, [33], Sr 24 also gave effective resistance to 16 stem rust races prevailing in Ethiopia including TTKSK and TTTTF races. In China, $\mathrm{Sr} 24$ is effective to races TKTTF, TTTTF, and other races [34-35]. Nevertheless, virulence to $\mathrm{Sr} 24$ such as TTKST are common in the $P$. graminis f. sp. tritici population in Kenya [3, 36-38] that are potentially to spread to Ethiopia where they are currently absent. Thus, deploying of wheat cultivars with sole Sr24 resistance to farmers is not advised.
Test genotypes such as ETBW 7580, ETBW 6939, ETBW 7058, ETBW 7523, ETBW 7912, ETBW 6161, ETBW 6921, ETBW 7915, ETBW 7207, ETBW 7681, ETBW 6696, ETBW 7008, ETBW 7496, ETBW 7539, ETBW 7189, ETBW 7587 and ETBW 8014 had showed final rust severity fluctuation due to environments, reflecting the behaviour of adult plant resistance.

According to [24], lines with ACI values of 0-20, 21-40 and 41-60 are regarded as possessing better, moderate and low levels of partial yellow rust resistance, respectively. Likewise, germplasm that had low seedling infection, low severity, ACI and high resistance reaction (R-MR) are commonly taken as all-stage resistant germplasm that is governed by race-specific resistance genes. Thus, based on these diseases parameter values, partial and race specific resistances are operating in various lines of bread wheat genotypes evaluated.

Developing resistant varieties combining both all-stage resistance and partial resistance determined by race specific and minor genes, respectively, is a priority research area for breeders in Ethiopia. Varieties with combination of resistance genes could be more durable and more effective than varieties with sole all-stage or adult plant resistance types. Therefore, 52 lines that had disease records characterizing indicating the presence of aforementioned of two types of resistances and still comparable to recently released varieties Shorima or Hulluka, the priority materials to be used for developing cultivars that could combining non-race specific and race specific genes and keep more durable [39] stem rust resistance than the resistance gene with major effect and more effective than adult plant resistance commonly affected by environmental variables.

\section{Conclusion}

Several bread wheat genotypes evaluated had the merits of the true partial/ adult plant resistance and race specific Srgene/s. Although Sixty six lines possessed final rust severity $\leq 30 \%$ and low ACI are acceptable for rust resistance breeding in wheat, 52 lines showed comparable resistance to Shorima or Hulluka are the priority materials to be used for developing cultivars combining non-race specific and race specific genes which is more durable than cultivars with major resistance gene effect. Stem rust resistance breeding programs working with parents' of known stem rust resistance gene/s is more efficient in stacking known Srresistance genes into a single cultivar. Thus, identification of stem rust resistance gene/s inherent in these resistant genotypes is relevant.

\section{Acknowledgements}

Authors are grateful to SARD-SC wheat project and Ethiopian Institute of Agricultural Research (EIAR) for financial support and Kulumsa Agricultural Research Center for provision of facilities and implementation of the experiment. We also would like to acknowledge Mr Neway 
Kebede, Ms Getenesh Demisse, Mr Teshome Tegegn and Mr Girma Zewude for the nursery management and data collection.

\section{References}

[1] Hailu Gebre-Mariam. 1991. Wheat production and research in Ethiopia. In: Hailu Gebre-Mariam, Tanner, D. G. and Mengistu Hulluka (eds.). Wheat research in Ethiopia: A historical perspective. Addis Ababa, IAR/CIMMYT. pp. 1-15.

[2] CSA. 2017. Central Statistical Agency. The Federal Democratic Republic of Ethiopia, Central Statistical gency, Agricultural Sample Survey 2016/17 (2009 E. C.), Volume I, Report on Area and Production of Major Crops (Private Peasant Holdings, Meher Season), Statistical Bulletin 584, April 2017, Addis Ababa, Ethiopia.

[3] Admassu B, Lind V, Friedt W, Ordon F. 2009. Virulence analysis of Puccinia graminis f. sp. Tritici populations in Ethiopia with special consideration of Ug99. Plant Pathology $58,362-369$.

[4] Ayele Badebo, Eshetu Bekele, Berhanu Bekele, Bekele Hundie, Melaku Degefa, Asnakech Tekalign, Melkamu Ayalew, Amare Ayalew Kiros Meles and Fekede Abebe, 2008, Review of two decades of Research on diseases of small cereal crops. Pp 375429. In Abraham Tadesse (eds). Increasing crop production through improved plant protection, volume 1 proceedings of the $14^{\text {th }}$ Annual conference of the plant protection society of Ethiopia (PPSE), 19-22 December 2006. Addis Ababa, Ethiopia. PPSE and EIAR, Adiss Ababa, Ethiopa. 598pp.

[5] Eshetu Bekele, 1986. Review of research on diseases of barley, tef and wheat in Ethiopia. Pp. 79-108. In: Tsedeke Abate (ed). A review of crop protection research in Ethiopia. Proceedings of the first crop protection symposium, IAR, Addis Ababa, Ethiopia.

[6] Mengistu Huluka, Getaneh Woldeab, Yeshi Andnew, Rebka Desta and Ayele Badebo. 1991. Wheat pathology research in Ethiopia. In: Hailu Gebre-Mriam, Tanner, D. G. and Mengistu Huluka (eds.). Wheat research in Ethiopia: A historical perspective. Addis Ababa; IAR/CIMMYT.

[7] Wafa Khoury, Keith Cressman and Amor Yahyaoui, 2008. Special Session:Ug99 Status, Management and Prevention. FAO, Rome 9 April 2008.

[8] Bekele Hundie. 2003. Short report on yellow rust and stem rust. In: Bedada Girma (ed). Bale Agricultural development enterprise. Proceedings of the Agronomy workshop, Addis Ababa, Ethiopia.

[9] McIntosh, RA, CR Wellings and RF Park. 1995. Wheat Rusts: An atlas of resistance genes. Plant Breeding Institute, The University of Sydney, CSIRO Australia 1995.

[10] Worku Denbel., Zerihun Tadasse, Daniel Kassa, Habte Zegaye, Dawit Asnake and Wamyera. R. 2016. Development of wheat germplasm for stem rust resistance in Eastern Africa. African Crop Science Journal, Vol. 24, Issue Supplement s1, pp. 25-33.

[11] Endale Hailu and Getaneh. Woldeab. 2015. Survey of Rust and Septoria Leaf Blotch Diseases of Wheat in Central Ethiopia and Virulence Diversity of Stem Rust Puccinia graminis f. sp. tritici. Adv Crop Sci Tech 3: 166. doi:10.4172/2329-8863.1000166.
[12] Endale Hailu, Getaneh Woldaeb, Worku Denbel, Wubishet Alemu, Tekelay Abebe, Agengehu Mekonnen..2015. Distribution of stem Rust (Puccinia graminis f. sp. tritici) Races in Ethiopia. Plant. Vol. 3, No. 2, 2015, pp. 15-19. doi: 10.11648/j.plant.20150302.11.

[13] Olivera, P., Newcomb, M., Szabo, L. J., Rouse, M. N., Johnson, J. L., Hodson, D., Luster, D. G., Cox, J., Burgin, L., Gilligan, C., Patpour, M., Hovmoller, M., Woldeab, G., Hailu, E., Hundie, B., Tadesse, K., Pumphrey, M., Singh, R., Jin, Y. 2015. Phenotypic and genotypic characterization of race TKTTF of Puccinia graminis f. sp. tritici that caused a wheat stem rust epidemic in southern Ethiopia in 2013-2014. Phytopathology. 105 (7):917-928.

[14] Johnson R. 1983. Genetic background of durable resistance. In: Lamberti F, Waller JM, Van der Graaff NA, ed. Durable Resistance in Crops. New York: Plenum, 5-24.

[15] Semenov MA, Halford NG (2009). Identifying target traits and molecular mechanisms for wheat breeding under a changing climate. J. Exper. Bot. 60 (10):2791 -2804.

[16] Burdon J. J (1993). Genetic variation in pathogen populations and its implications for adaptation to host resistance. Durability of disease resistance. Th. Jacobs and J. E. Parlevliet (Eds). Kluwer Academic Publishers, Norwell, MA. pp. 41 -56.

[17] Singh R. P, Hodson D. P, Huerta-Espino J, Jin Y, Njau P, Wanyera R, Herrera-Foessel SA, Ward RW (2008). Will Stem Rust Destroy the World's Wheat Crop? Adv. Agron. 98:271 309 .

[18] Sing R. P., Hadson, D. P., Huerta-Epino, T., Jin, Y., Bhavani, s., Njau, P., Herreta-Foessel, S, A., Sing, P. K., Sing, S., and Govindan, V. 2011. The emergence of ug99 races of stem rust is a threat to world wheat production. Annu. Rev. phytopathol. 49:465-481.

[19] Jin Y, Singh RP, Ward RW, Wanyera R, Kinyua M, Njau P, Fetch T, Pretorius ZA, Yahyaoui A. 2007. Characterization of seedlinginfection types and adult plant infection responses of monogenic Srgene lines to race TTKS of Puccinia graminis $\mathrm{f}$. sp. tr. tici. Plant Dis. 91:1096-1099.

[20] Peterson R. F, Campbell A. B, Hannah A. E, (1948) A diagrammatic scale for estimating rust intensity on leaves and stems of cereals. Can J Res 26: 496-500.

[21] Roelfs AP, Singh RP, Saari EE (1992). Rust Diseases of Wheat: Concepts and Methods of Disease Management. CIMMIYT, Mexico, DF. ISBN: 968-6127-70-4 p. 81.

[22] Duncan Cheruiyot, Pascal P. Okwiri Ojwang, Peter N. Njau, Peter F. Arama, Sridhar Bhavani. 2015. Evaluation of advanced wheat (Triticum aestivum L.) lines for stem rust (Puccinia graminis f. sp. tritici) resistance and yield. IJAAR, Vol. 6, No. 3, p. 57-70.

[23] Stakman EC, Stewart DM, Loegering WQ (1962). Identification of physiologic races of Puccinia graminis var. tritici. U.S, Agric. Res. Serv. ARS E617:1-53.

[24] ALI, S, S. J. A. Shah and K. Maqbool. 2008. Field-based assessment of partial resistance to yellow rust in wheat Germplasm. J Agric Rural Dev 6 (1\&2), 99-106.

[25] Parlevliet, J. E., Van-Ommeren, A. 1975. Partial resistance of barley to leaf rust, Puccinia hordei. II. Relationship between field trials, micro plot tests and latent period. Euphytica 24, 293-303. 
[26] Herrera-Foessel, S. A., Singh, R. P., Huerta-Espino, J., Crossa, J., Djurle, A., Yuen, J. 2007. Evaluation of slow rusting resistance components to leaf rust in CIMMYT durum wheats. Euphytica 155, 361-369.

[27] Parlevliet, J. E. 1988. Resistance of the Non-Race-Specific Type. In "The Cereal Rusts", Vol. II. Diseases, Distribution, Epidemiology and Control, Academic Press, Orelando.

[28] Mulugeta N. 1986. Estimates of phenotypic diversity and breeding potential of Ethiopian wheats. Hereditas 104: 41-48.

[29] Masresha Aklilu. 1996. Wheat rust races identified in virulence surveys in Ethiopia. The Ninth Regional Wheat Workshop for Eastern, Central and Southern Africa. Addis Ababa, Ethiopia: CIMMYT.

[30] Alemayehu Hailu, Getaneh Woldeab, Woubit Dawit and Endale Hailu. 2015. Evaluation of bread wheat varieties to dominant races of stem rust (Puccinia graminis f. sp. tritici) Pathogen. Science Innovation 3 (6): 121-126.

[31] Netsanet Hei, Hussein Ali Shimelis, Mark Laing and Belayneh Admassu. 2015. Assessment of Ethiopian wheat lines for slow rusting resistance to stem rust of wheat caused by Puccinia graminis f.sp.tritici. J.Phytopathol 163, 353-363.

[32] Tolessa Taye, Chemada Fininsa and Getaneh Woldeab. 2014. Evaluation of wheat cultivars for slow rusting resistance in Guji zone Southern Oromia. African Journal of Agricultural Research. Vol. 9 (46), pp3388-3392.

[33] Lemma A, Woldeab G, Semahegn Y. 2015. Virulence Spectrum of Wheat Stem Rust (Puccinia graminis f.sp.tritici) in the Eastern Showa of Central Ethiopia. Adv Crop Sci Tech S1: 008. doi:10.4172/2329-8863.S1-008.
[34] Bhattacharya S. 2017. Deadly new wheat disease threatens Europe's crops. Nature 542:145-146 DOI 10.1038/nature.2017.21424.

[35] Han JD, Cao YY, Sun ZG. 2010. 2007-2008 Race dynamics of Puccinia graminis f. sp. tritici in China and the virulence of CIMMYT wheat germplasm resistant to Ug99. Journal of Triticeae Crops 30:163-166.

[36] Jin, Y., Szabo, L. J., Pretorius, Z. A., Singh, R. P., Ward, R., and Fetch, T., Jr. 2008. Detection of virulence to resistance gene Sr24 within race TTKS of Puccinia graminis f. sp. tritici. Plant Dis. 92:923-926.

[37] Jin, Y., Szabo, L. J., Rouse, M. N., Fetch T. Jr, Pretorious, Z. A., Wanyera, R. and Njau, P. 2009. Detection of virulence to resistance gene Sr36 within the TTKS race lineage of Puccinia graminis f.sp. tritici. Plant Disease 93: 367-370.

[38] Newcomb, M., Olivera, P. D., Rouse, M. N., Szabo, L. J., Johnson, J., Gale, S., Luster, D. G., Wanyera, R., Macharia, G., Bhavani, S., Hodson, D., Patpour, M., Hovmøller, M. S., Fetch, T. G., Jr., and Jin, Y. 2016. Kenyan isolates of Puccinia graminis f. sp. tritici from 2008 to 2014: Virulence to SrTmp in the Ug99 race group and implications for breeding programs. Phytopathol. 106:729-736.

[39] Ellis JG, Lagudah ES, Spielmeyer W, Dodds PN. 2014. The past, present and future of breeding rust resistant wheat. Front Plant Sci. 5:641. https://doi.org/10.3389/fpls.201 4.00641 PMID: 2550547. 